\title{
Pengaruh Suhu dan Waktu Kempa Terhadap Sifat Fisik dan Mekanik Papan Komposit dari Serat Tkks Berperekat Gambir Berlapis Anyaman Bambu
}

\author{
Influence of Temperature and Pressing Time on The Physical and \\ Mechanical Characteristics of Woven Bamboo Veneer Composite Board \\ Made From Empty Palm Oil Fruit Bunch Fibers and Gambir Based Adhesive
}

Junaidi

Jurusan Teknik Mesin Politeknik Negeri Padang Kampus Limau Manis Padang

Telp. 0751-72590 Fax. 0751-72576 Email: junaidisyampoltek@gmail.com

\begin{abstract}
Fiber from oil palm empty fruit bunches (OPEFB) can be used as a raw material for the production of composite board. Gambier can be used in a natural adhesive because of its high tannin content. Appropriate material to veneer the board and the correct temperature and pressing time are needed to improve the quality of this composite board. This research was to discover the optimal temperature, needed to make woven bamboo veneer composite board from OPEFB fiber and gambier based adhesive that can fulfill the Indonesian National Standards for veneered composite boards and the pressing time required for the board to reach thermal equilibrium. Results showed that both temperature and pressing time have a significant influence on density, moisture content, thickness swelling and modulus of rupture (MOR) of the boards but not on the internal bond strength or the compression strength parallel to the grain. Multi-layered composite board pressed at $130^{\circ} \mathrm{C}$ has weaker physical and mechanical properties than that pressed at $145^{\circ} \mathrm{C}$, or $160^{\circ} \mathrm{C}$. Twenty-five minutes of pressing time yielded a better product than 15 minutes and the combination of 25 minutes and $145^{\circ} \mathrm{C}$ proved to be optimal for the curing of the gambier based adhesive used with $8.4 \%$ moisture content fibers. Use of woven bamboo veneer resulted in boards that reached the density, moisture content, thickness swelling at 24 hours (PT24) and MOR National standards SNI 03-2105-2006 for standard veneered particle board however it failed to reach the standard for modulus of elasticity (MOE). The bonding strength of the boards reached the Nation Standard SNI 01-5008.7-1999 of 3.5 kg/ $\mathrm{cm}^{2}$ minimum for structural veneered boards.
\end{abstract}

Keywords: Veneered Composite Boards, Tannin Adhesive, Fiber Mechanics, Building Materials

\section{PENDAHULUAN}

(TKKS) kandungan serat $\pm 70 \%$, diperkirakan jumlahnya di Indonesia \pm 9.284.679,3 ton (Departemen Pertanian, 2015). Serat TKKS dapat diuraikan secara mekanis untuk produk komersil dan bisa digunakan sebagai bahan baku produk papan komposit berbasis serat seperti papan partikel (Junaidi, Anwar Kasim, Adrinal., 2016). Begitu juga gambir sebagai perekat alami papan komposit, karena didalamnya terdapat kandungan tanin cukup tinggi 25$55 \%$ (Kasim, 2002).

Beberapa hasil penelitian pembuatan papan komposit menggunakan perekat tanin yaitu, pembuatan papan komposit dari partikel kayu jeungjing dan perekat tanin dari ekstrak kulit kayu bakau (Sumadiwangsa, 1982), didapatkan sifat mekanis papan partikel menurut standar FAO (1958). Papan partikel dari kayu acacia mangium wild dengan perekat tanin dari kulit kayu acacia decurrens wild dengan penambahan formaldehida (Syafii, 2000). Papan komposit lamina dua lapis dari kayu sengon dengan perekat tanin bakau (Rhizophora spp) (Cicilia, 2000). Papan partikel tipe eksterior dari perekat tanin resorsisol formaldehida menggunakan partikel kayu karet (Iputu, 2005). Begitu juga pembuatan papan komposit dari serat TKKS menggunakan perekat gambir yaitu, papan komposit dalam bentuk papan partikel dari serat TKKS dengan perekat kulit akasia dan gambir (Umi Fatanah, 
2013). Papan komposit dengan perekat gambir (Kasim, 2011). Hasil penelitiannya didapatkan kondisi optimum dengan kerapatan papan $0,8 \mathrm{~g} / \mathrm{cm}^{3}$, dan sebahagian sifat papan telah memenuhi Standar Nasional Indonesia (SNI). Walaupun begitu satu kelemahan yang ada pada papan komposit, khususnya papan partikel adalah sifat mekanisnya yang rendah dibandingkan dengan kayu solid.

Untuk meningkatkan kekuatan serta penampilan papan komposit adalah dengan penambahan bahan pelapis face dan back pada permukaan papan komposit tersebut (Haygreen dan Bowyer, 1993). Dasar pemikirannya adalah dengan adanya bahan pelapis kemampuan papan untuk menerima beban akan meningkat, salah satunya adalah anyaman bambu (Sudijono dan Subyakto 2002). Penelitian papan komposit berlapis anyaman bambu pada bagian muka dan belakang dengan serat sabut kelapa dapat meningkatkan sifat mekanis papan komposit (Setyawati, 2009). Begitu juga pemakaian anyaman bambu miring sebagai bahan pelapis papan komposit dari serat kayu cepat tumbuh dapat meningkatkan nilai MOR dan MOE papan 50\%, dan pemakaian anyaman bambu tegak lurus dapat meningkatkan MOR dan MOE $120 \%$ dibandingkan dengan papan tanpa lapisan (Erniwati, 2008).

Selanjutnya kwalitas papan komposit yang diberi lapisan sangat dipengaruhi oleh suhu dan waktu pengempaan (Maloney, 1993). Selama proses pengempaan, papan komposit dengan cepat mengalami berbagai perubahan internal yang menentukan sifatsifat akhir papan yaitu sifat fisis dan mekanis (Kollman, 1975). Suhu dan waktu kempa sangat berkaitan dengan penggunaan jenis perekat dan bahan baku papan. Perlakuan waktu pengempaan berpengaruh nyata terhadap kadar air papan partikel, dan suhu pengempaan berpengaruh nyata terhadap kerapatan, keteguhan rekat dan keteguhan patah (MOR) (Kasim, 2007). Selanjutnya dengan bertambahnya suhu dari $100^{\circ} \mathrm{C}$ menjadi $120^{\circ} \mathrm{C}$ sifat mekanis papan komposit baik nilai MOR, MOE, IB dan kuat pegang sekrup akan semakin meningkat, tetapi cenderung menurun jika suhu dinaikkan lagi (Erniwaty, 2008). Dengan naiknya suhu pengempaan, waktu perekat untuk matang (cure) semakin singkat karena terjadi heat transfer yang cepat menyebabkan perekat mengalami pengerasan sebelum terpenetrasi ke dalam kayu sehingga menurunnya kekuatan papan (Sutigno, 1988).

Penelitian ini bertujuan untuk mengetahui suhu optimal yang diperlukan untuk mendapatkan kualitas papan komposit dari serat TKKS berperekat gambir berlapis anyaman bambu yang dapat memenuhi standar Nasional Indonesia (SNI 03-2105-2006) dan (SNI 01-5008.7-1999) untuk standar papan komposit berlapis. Selain itu, untuk mengetahui lama waktu pengempaan yang dibutuhkan agar bagian tengah papan komposit tersebut mencapai suhu yang sama dengan suhu bagian luar papan.

\section{METODOLOGI}

\section{A. Bahan dan Alat Penelitian}

Bahan yang digunakan pada penelitian ini adalah serat TKKS, perekat gambir, dan anyaman bambu. Bahan untuk pembuatan perekat adalah paraformaldehida, $\mathrm{NaOH} 50 \%$, dan air. Alat yang digunakan dalam pembuatan papan komposit yaitu, blender, ayakan, $\mathrm{PH}$ meter, stopwatch, alat kempa dingin dan kempa panas, neraca analit, dan alat uji sifat mekanis papan komposit (Universal Testing Machinel UTM, merk Galbadini).

\section{B. Metode}

Kerapatan sasaran papan $0,8 \mathrm{~g} / \mathrm{cm}^{3}$, ukuran $30 \mathrm{~cm}$ x $30 \mathrm{~cm}$ x $1,5 \mathrm{~cm}$. Perekat gambir dan Serat TKKS dicampurkan secara manual dan mekanis, dengan kadar perekat $16 \%$ dari berat papan, dan dilakukan pengempaan pada tekanan 25 $\mathrm{kg} / \mathrm{cm}^{2}$. Rancangan penelitian adalah rancangan acak dengan dua faktor yaitu: Faktor A: suhu $130^{\circ} \mathrm{C}, 145^{\circ} \mathrm{C}, 160^{\circ} \mathrm{C}$. Factor B: lama pengempaan, 15 menit, 25 
menit, 35 menit. Jumlah perlakuan 9 dan 2 ulangan, jumlah papan 18 buah. Bila pada analisis sidik ragam terdapat pengaruh yang nyata dan sangat nyata maka dilakukan uji lanjutan menurut Duncan News Multiple Range Test pada taraf nyata 5\%.

\section{Pelaksanaan Penelitian}

Penyediaan serat TKKS: Bahan baku serat TKKS adalah TKKS cacahan yang sudah dipress diambil dari pabrik kelapa sawit PT. Agrowiratama Pasaman Barat Sumatera Barat, kemudian TKKS tersebut diuraikan pada putaran $900 \mathrm{rpm}$ menggunakan mesin pengurai (defibrator) hasil penelitian sebelumnya untuk mendapatkan serat bersih (Gambar 1). Dari hasil penguraian didapatkan serat bersih dengan kadar air 9,2\%.

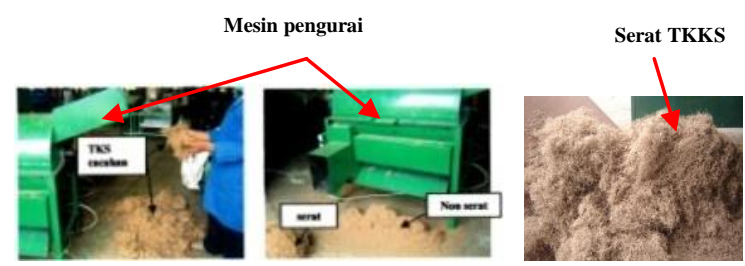

Gambar 1. Proses Penguraian serat TKKS

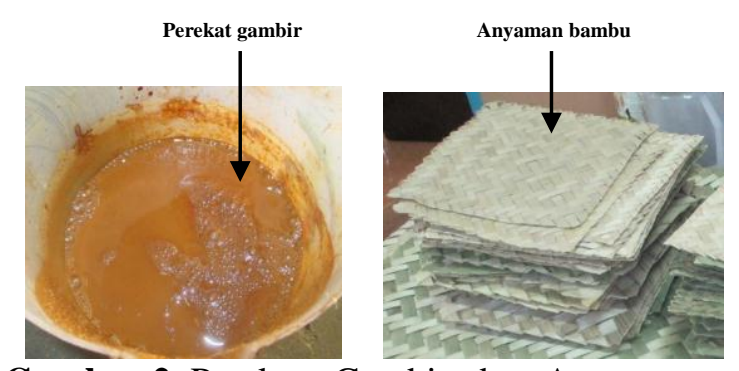

Gambar 2. Perekat Gambir dan Anyaman Bambu

Penyediaan anyaman Bambu dan Perekat Gambir : Digunakan anyaman bambu tanpa kulit dari bambu tali dengan tebal $1 \mathrm{~mm}$ dan lebar $10 \mathrm{~mm}$. Untuk pembuatan perekat digunakan gambir kelas 1 mutu super yang telah dihaluskan. Proses pembuatan perekat gambir dimulai dengan membuat larutan gambir 45 gram untuk 100 $\mathrm{ml}$ air dan diatur $\mathrm{PH}$ nya 8 dengan meneteskan $\mathrm{NaOH} 50 \%$. Kedalam larutan ditambahkan paraformaldehida $10 \%$ dan perekat siap digunakan. Perekat gambir dan anyaman bambu disajikan seperti pada Gambar 2.

\section{Pembuatan Papan Komposit}

Ukuran papan komposit $30 \mathrm{~cm}$ x 30 $\mathrm{cm} \times 1,5 \mathrm{~cm}$ dengan target kerapatan 0,8 $\mathrm{gr} / \mathrm{cm}^{2}$, jumlah serat untuk tiap lembar papan yaitu 908 gr berat kering oven, dengan kadar perekat $16 \%$ jumlah perekat yang digunakan 184,32 gr, jumlah paraformaldehida $18,4 \mathrm{gr}$, diatur $\mathrm{pH}$ nya 8 dengan meneteskan beberapa tetes $\mathrm{NaOH}$ $50 \%$ dan diukur dengan $\mathrm{pH}$ meter. Perekat gambir disemprotkan kedalam serat dan diaduk sampai homogen. Kemudian hasil campuran serat dengan perekat dimasukkan kedalam cetakan, dan sebelumnya dilapisi anyaman bambu dibawah dan diatas serat. Calon papan dikeluarkan dari cetakan, dilanjutkan dengan pengempaan dingin dan pengempaan panas. Selesai pengempaan dilanjutkan dengan pengkondisian dan diakhiri dengan pengujian sifat papan.

\section{E. Pengujian Sifat Papan Komposit}

Sifat papan komposit yang diamati yaitu, sifat fisik dan sifat mekanik seperti kerapatan, kadar air, pengembangan tebal 24 jam, keteguhan patah (MOR), internal bonding (IB), dan keteguhan tekan sejajar permukaan. Cara pengamatan dilakukan berpedoman kepada standar Nasional Indonesia (SNI) 03-2105-2006 dan SNI 015008.7-1999 untuk nilai keteguhan rekat, kecuali untuk pengamatan keteguhan tekan sejajar permukaan. Sampel untuk keteguhan tekan sejajar permukaan $5 \times 5 \mathrm{x} \mathrm{t} \mathrm{cm} \mathrm{(tebal}$ papan). Posisi sampel adalah berdiri dengan luar bidang kempa $5 \mathrm{~cm} \times \mathrm{t} \mathrm{cm}$. Beban diberikan pada bidang kempa sampai sampel pecah/rusak.

\section{HASIL DAN PEMBAHASAN}

\section{A. Data Penelitian}

Papan komposit berlapis yang dihasilkan seperti pada Gambar 3. Ditengah papan komposit adalah papan partikel dari serat TKKS bercampur perekat gambir berfungsi sebagai core dan lapisan anyaman 
bambu tanpa kulit pada bagian muka dan belakang.
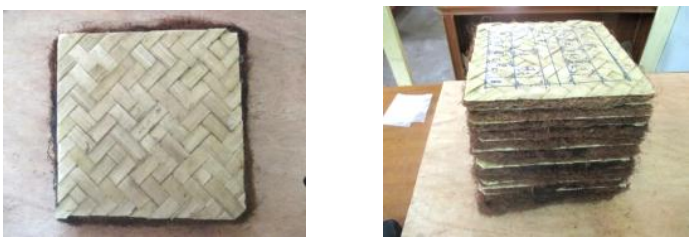

Gambar 3. Papan Komposit Berlapis Berdasarkan Waktu dan Suhu Kempa

Pengujian sifat fisik dan mekanik papan komposit dilakukan untuk melihat kualitas papan komposit berdasarkan standar SNI 03-2105-2006 dan SNI 015008.7-1999. Data hasil pengujian sifat fisik dan mekanik papan komposit seperti pada Tabel 1.

Tabel 1. Data Pengujian Sifat Fisis dan Mekanis Papan Komposit Berlapis Anyaman Bambu pada Berbagai Suhu dan Waktu Kempa

\begin{tabular}{|c|c|c|c|c|c|c|c|c|}
\hline \multicolumn{2}{|c|}{ Perlakuan } & \multirow{2}{*}{$\begin{array}{c}\mathrm{KR} \\
\left(\mathrm{g} / \mathrm{cm}^{3}\right)\end{array}$} & \multirow{2}{*}{$\begin{array}{l}\text { KA } \\
\%)\end{array}$} & \multirow{2}{*}{$\begin{array}{l}\text { PT24 } \\
(\%)\end{array}$} & \multirow{2}{*}{$\begin{array}{c}\text { MOR } \\
\left(\mathrm{kg} / \mathrm{cm}^{2}\right)\end{array}$} & \multirow{2}{*}{$\begin{array}{c}\text { MOE } \\
\left(10^{4}\right. \\
\left.\mathrm{kg} / \mathrm{cm}^{2}\right)\end{array}$} & \multirow{2}{*}{$\begin{array}{c}\text { IB } \\
\left(\mathrm{kg} / \mathrm{cm}^{2}\right)\end{array}$} & \multirow{2}{*}{$\begin{array}{c}\mathrm{KT} \\
\left(\mathrm{kg} / \mathrm{cm}^{2}\right)\end{array}$} \\
\hline $\begin{array}{l}\text { Suhu } \\
\left({ }^{\circ} \mathrm{C}\right)\end{array}$ & $\begin{array}{l}\text { Waktu } \\
\text { (menit) }\end{array}$ & & & & & & & \\
\hline \multirow{3}{*}{ A1 } & B1 & 0,76 & 13,5 & 15,2 & 159,4 & 0,54 & 3,55 & 80,9 \\
\hline & B2 & 0,78 & 11,8 & 14,8 & 222,8 & 1,09 & 3,69 & 93,2 \\
\hline & B3 & 0,83 & 11,1 & 14,6 & 258,5 & 1,06 & 4,26 & 119,7 \\
\hline \multirow{3}{*}{ A2 } & B1 & 0,79 & 11,8 & 12,2 & 220,7 & 0,76 & 4,30 & 82,0 \\
\hline & B2 & 0,81 & 11,3 & 10,9 & 230,4 & 1,03 & 4,16 & 108,4 \\
\hline & B3 & 0,84 & 10,8 & 10,6 & 268,3 & 1,41 & 3,42 & 109,5 \\
\hline \multirow{3}{*}{ A3 } & B1 & 0,87 & 11,0 & 13,1 & 206,6 & 1,08 & 3,77 & 86,8 \\
\hline & B2 & 0,91 & 10,8 & 13,5 & 270,4 & 1,32 & 4,06 & 104,4 \\
\hline & B3 & 0,86 & 10,6 & 12,6 & 295,3 & 1,84 & 4,34 & 119,8 \\
\hline \multicolumn{2}{|r|}{ SNI } & $0,4-0,9$ & $<14$ & $<25$ & $>153$ & $>2,86$ & $3,5-<7$ & - \\
\hline
\end{tabular}

Keterangan:

$\mathrm{A} 1=$ Suhu $130^{\circ} \mathrm{C}$ KA $=$ Kadar air $(\%)$

$\mathrm{A} 2=$ Suhu $145^{\circ} \mathrm{C}$ PT24 = Pengembangan tebal 24 jam

$\mathrm{A} 3=$ Suhu $160^{\circ} \mathrm{C}$ MOR $=$ Modulus of

Rupture $\left(\mathrm{kg} / \mathrm{cm}^{2}\right)$

$\mathrm{B} 1=$ Waktu 15 MOE $=$ Modulus Of menit Elastisitas $\left(10^{4}\right.$ $\mathrm{kg} / \mathrm{cm}^{2}$ )

B2 = Waktu 25 IB = Internal Bonding menit $\left(\mathrm{kg} / \mathrm{cm}^{2}\right)$

B3 = Waktu 35 KT = Keteguhan tekan menit sejajar serat

$\mathrm{KR}=$ Kerapatan $\left(\mathrm{kg} / \mathrm{cm}^{2}\right)$ $\left(\mathrm{g} / \mathrm{cm}^{3}\right)$

\section{B. Sifat Fisik Papan Komposit}

Kerapatan (KR): Nilai kerapatan papan komposit berkisar $0,76-0,91 \mathrm{~g} / \mathrm{cm}^{3}$ (Gambar 4). Nilai kerapatan papan sebagian besar berada dibawah kerapatan sasaran yang ditetapkan yaitu $0,8 \mathrm{~g} / \mathrm{cm}^{3}$. Nilai kerapatan yang tertinggi pada suhu $160^{\circ} \mathrm{C}$ dengan waktu pengempaan 25 menit, nilai kerapatan yang terendah pada $130^{\circ} \mathrm{C}$ dengan waktu pengempaan 15 menit. Rata-rata kerapatan papan memenuhi standar SNI 03-2105-2006, yaitu $0,4 \mathrm{~g} / \mathrm{cm}^{3}-0,9 \mathrm{~g} / \mathrm{cm}^{3}$.

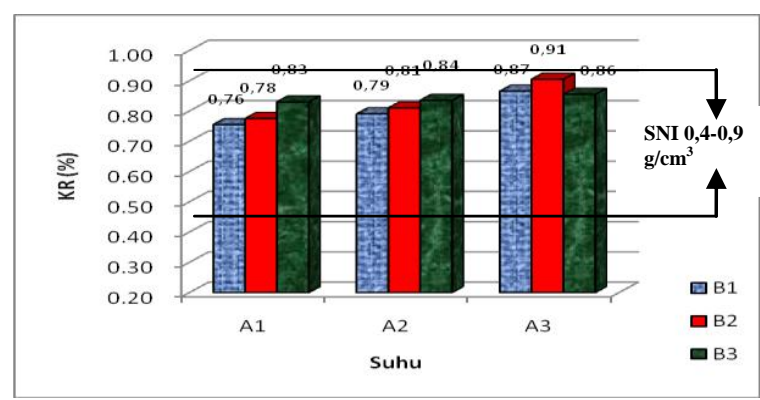

Gambar 4. Kerapatan Papan Komposit Berlapis pada Berbagai Suhu dan waktu Kempa

Dari hasil sidik ragam, variasi suhu dan waktu pengempaan berpengaruh nyata terhadap kerapatan papan komposit dan ada interaksi diantara kedua faktor tersebut. Kerapatan papan komposit semakin meningkat dari waktu pengempaan 15 menit menjadi 35 menit, hal ini terlihat pada papan komposit dengan suhu $130^{\circ} \mathrm{C}$ dan $145^{\circ} \mathrm{C}$, tetapi pada suhu $160^{\circ} \mathrm{C}$ kerapatan papan komposit menurun dari lamanya pengempaan 25 menit ke 35 menit. Hal ini diduga dengan suhu $160^{\circ} \mathrm{C}$ waktu pengempaan 25 menit, perekat dengan serat sudah menyatu dan ikatannya menjadi kuat. Hal ini berarti perekat gambir membutuhkan waktu 25 menit sebagai waktu optimal terjadinya curing, dan setelah melewati waktu tersebut dengan waktu 35 menit papan akan semakin kering akibat pemanasan yang terlalu lama, sehingga permukaan papan akan hangus dan berat papan semakin ringan. Dibandingkan dengan waktu pengempaan 25 menit otomatis kerapatannya menurun.

Kadar air (Ka): Kadar air papan komposit berkisar dari 10,58\%-13,5\% (Gambar 5). Hasil sidik ragam, menunjukkan bahwa pengaruh variasi suhu 
dan lama pengempaan berpengaruh nyata terhadap kadar air papan komposit, tetapi tidak ada interaksi antara kedua faktor tersebut.

Hasil uji lanjut pada taraf $\alpha 5 \%$, kadar air papan komposit tidak memperlihatkan perbedaan yang signifikan antara suhu $130^{\circ} \mathrm{C}$ dengan $145^{\circ} \mathrm{C}$ (A1-A2), suhu $130^{\circ} \mathrm{C}$ dengan $160^{\circ} \mathrm{C}$ (A1-A3) dan suhu $145^{\circ} \mathrm{C}$ dengan $160^{\circ} \mathrm{C}$ (A2-A3), begitu juga waktu 15 menit dengan waktu 25 menit (B1-B2), 15 menit dengan 35 menit (B1-B3) dan waktu 25 menit dengan 35 menit (B2-B3). Kadar air papan komposit semakin berkurang dengan naiknya suhu pengempaan, tetapi perbedaan pengurangan kadar air pada suhu pengempaan $130{ }^{\circ} \mathrm{C}$ dengan $145{ }^{0} \mathrm{C}$ tidak begitu jauh, begitu juga $130^{\circ} \mathrm{C}$ dengan $160^{\circ} \mathrm{C}$. Hal tersebut menunjukkan bahwa semakin tinggi suhu dan semakin lama waktu kempa yang digunakan, kadar air papan akan semakin berkurang, tetapi pengurangannya tidak efektif lagi jika telah mencapai titik tertentu.

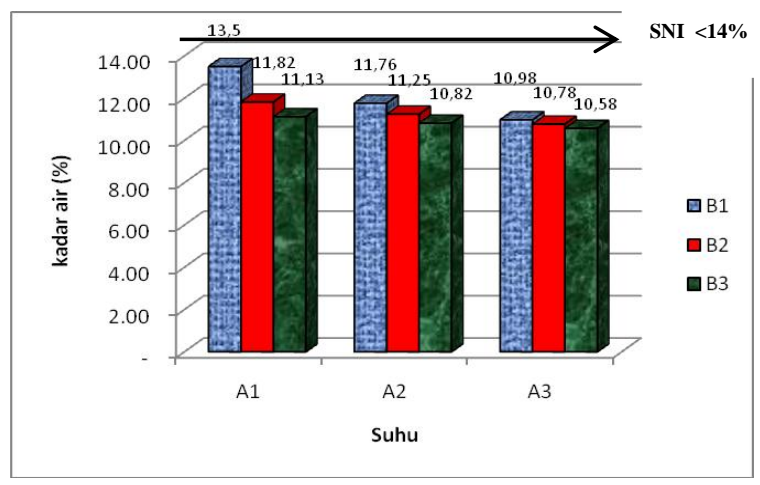

Gambar 5. Kadar Air Papan Komposit Berlapis pada Berbagai Suhu dan Waktu Kempa

Umumnya kadar air papan komposit terutama ditentukan oleh kadar air bahan bakunya (Kelly, 1977). Walaupun terdapat perbedaan kadar air yang nyata pada penelitian ini, namun perbedaan tersebut relatif kecil. Nilai kadar air serat yang digunakan pada penelitian ini kecil $(8,4 \%)$ dan kerapatan papan komposit yang dihasilkan sebagian besar diatas kerapatan papan sasaran $\left(0,8 \mathrm{~kg} / \mathrm{cm}^{2}\right)$. Pada umumnya sifat-sifat papan komposit yang dihasilkan sangat dipengaruhi oleh nilai kerapatan papan komposit tersebut (Maloney, 1993). Papan dengan kerapatan yang tinggi memiliki ikatan antara molekul partikel dengan molekul perekat terbentuk dengan kuat sehingga molekul air sulit mengisi rongga yang terdapat dalam papan komposit karena telah terisi oleh molekul perekat (Ruhendi dkk., 2007).

Berdasarkan standar SNI 03-21052006, maka kadar air semua papan komposit yang dihasilkan memenuhi standar yang mensyaratkan kadar air papan komposit maksimal 14\%

Pengembangan Tebal 24 jam (PT24): PT24 papan komposit semakin menurun pada suhu $130^{\circ} \mathrm{C}$ ke suhu $145^{\circ} \mathrm{C}$ dan naik lagi pada suhu $160^{\circ} \mathrm{C}$. PT24 papan komposit pada suhu $130^{\circ} \mathrm{C}$ dengan waktu kempa 15 menit adalah 15,17\%, 25 menit $14,80 \%$ dan 35 menit $14,55 \%$ dengan perbedaan sangat sedikit sekali, sehingga variasi waktu kempa 15 menit, 25 menit dan 35 menit tidak begitu mempengaruhi PT24 papan komposit, hal ini disebabkan PT24 papan komposit sangat dipengaruhi oleh kadar air papan komposit yang dihasilkan. Pada suhu $145^{\circ} \mathrm{C}$ PT24 papan komposit dengan waktu kempa 15 menit adalah 12,23\%, waktu kempa 25 menit $10,91 \%$ dan waktu kempa 35 menit $10,62 \%$. Terjadi perbedaan PT24 papan komposit yang agak besar pada waktu kempa 15 menit dengan 25 menit, sedangkan waktu kempa 25 menit dengan 35 menit perbedaanya sedikit sekali, hal ini kemungkinan disebabkan terjadi penurunan kadar air papan komposit yang besar pada waktu kempa 15 menit dengan 25 menit, dan pada waktu pengempaan 35 menit penurunan kadar air papan komposit tidak efektif lagi. Selanjutnya pada suhu $160^{\circ} \mathrm{C}$ terjadi kenaikan PT24 papan komposit pada masing-masing waktu kempa (15 menit, 25 menit dan 35 menit), perbedaannya sedikit sekali. Hal ini kemungkinan disebabkan suhu diatas $145^{\circ} \mathrm{C}$ kadar air papan komposit semakin kecil, dengan naiknya suhu pengempaan sampai pada $160^{\circ} \mathrm{C}$ penurunan 
kadar air papan komposit tidak efektif lagi, serat mulai menghitam / gosong dan sewaktu direndam dengan air 24 jam, partikel air mudah memasuki ronggarongga papan komposit dan terjadi PT24 papan komposit yang lebih besar.

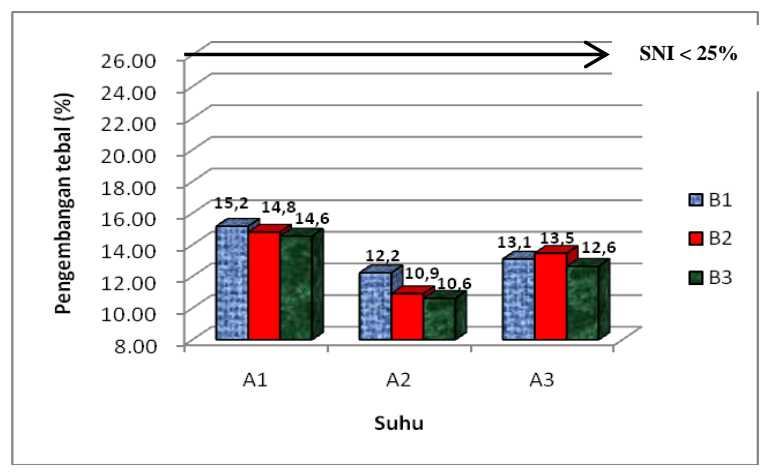

Gambar 6. Pengembangan Tebal Papan Komposit Berlapis pada Berbagai Suhu dan Waktu Kempa

Jika dibandingkan dengan standar SNI 03-2105-2006, maka PT24 papan komposit dihasilkan memenuhi standar yang mensyaratkan PT24 papan maksimal $25 \%$.

\section{Sifat Mekanis Papan Komposit}

Nilai Modulus of Rupture (MOR):

Nilai Modulus of Rupture (MOR) merupakan kemampuan papan untuk menahan beban tegak lurus permukaan papan hingga batas maksimum. Hasil penelitian memperlihatkan Nilai MOR papan komposit berkisar antara 159,44 $\mathrm{kg} / \mathrm{cm}^{2}-295,31 \mathrm{~kg} / \mathrm{cm}^{2}$, seperti tertera pada Gambar 7.

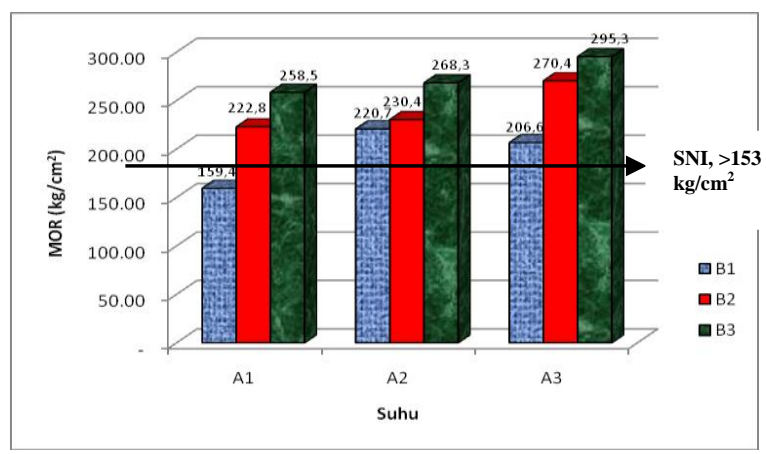

Gambar 7. MOR Papan Komposit Berlapis Pada Berbagai Suhu dan Waktu Kempa
Hasil sidik ragam menunjukkan variasi suhu dan waktu pengempaan berpengaruh nyata terhadap Nilai MOR papan komposit, tetapi tidak ada interaksi antara kedua faktor tersebut. Hasil uji lanjut pada taraf $\alpha 5 \%$ didapatkan papan komposit dengan suhu $130^{\circ} \mathrm{C} 145^{\circ} \mathrm{C}$ dan $160^{\circ} \mathrm{C}$ yang masing-masing $\mathbf{S N I},<25 \%$ reda nyata, sedangkan variasi waktu kempa 15 menit berbeda nyata dengan waktu 25 menit dan 35 menit, dan waktu 25 menit dengan 35 menit tidak berbeda nyata. Hal ini terjadi karena papan komposit yang dihasilkan dengan waktu kempa 25 menit dan 35 menit, perekat gambir yang digunakan telah mencapai waktu yang dibutuhkan pada masing-masing suhu agar terjadinya proses pengerasan perekat sehingga menghasilkan kekuatan rekat yang baik. Hal ini berimplikasi pada lebih tingginya kekuatan papan menahan beban.

Papan komposit pada suhu $130^{\circ} \mathrm{C}$ semakin meningkat nilai MOR nya secara signifikan dari waktu pengempaan 15 menit yaitu $150,44 \mathrm{~kg} / \mathrm{cm}^{2}$ dengan waktu 25 menit $222,84 \mathrm{~kg} / \mathrm{cm}^{2}$ dan waktu 35 menit 258,53 $\mathrm{kg} / \mathrm{cm}^{2}$. Besarnya peningkatan nilai MOR papan komposit pada suhu $130^{\circ} \mathrm{C}$ ini karena nilai kerapatan papan komposit yang dihasilkan juga semakin besar, disamping itu dalam proses pembuatan papan komposit dengan proses pengadukan secara mekanis, perekat gambir penyebarannya sangat merata dan pada waktu pengempaan dengan tekanan yang kuat perekat memasuki rongga-rongga papan, sehingga perekat dengan serat saling mengunci (interlocking).

Penggunaan lapisan anyaman bambu ini mengakibatkan keteguhan patah papan komposit yang dihasilkan dapat memenuhi standar SNI 03-2105-2006 untuk standar papan partikel berlapis finir, dan semua papan komposit hasil penelitian ini nilai keteguhan patahnya melebihi standar SNI 03-2105-2006.

Nilai Modulus of Elastisitas (MOE): Modulus elastisitas papan komposit yang dihasilkan antara $0,54 \times 10^{4} \mathrm{~kg} / \mathrm{cm}^{2}-1,84$ 
$\mathrm{kg} / \mathrm{cm}^{2}$. Nilai MOE terendah pada papan komposit dengan suhu pengempaan $130{ }^{0} \mathrm{C}$ dan waktu pengempaan 15 menit, sedangkan nilai MOE tertinggi papan komposit dengan suhu pengempaan $160{ }^{\circ} \mathrm{C}$ dan waktu pengempaan 35 menit. Nilai rata-rata pengujian disajikan pada Gambar 8. Nilai MOE papan komposit cenderung meningkat dengan meningkatnya suhu dan waktu kempa, karena pada suhu tinggi perekat lebih cepat mengalir mengisi rongga-rongga papan dan waktu kempa yang lebih lama menyebabkan perekat dapat terdistribusi lebih merata sehingga kontak antara perekat dan serat menjadi lebih besar.

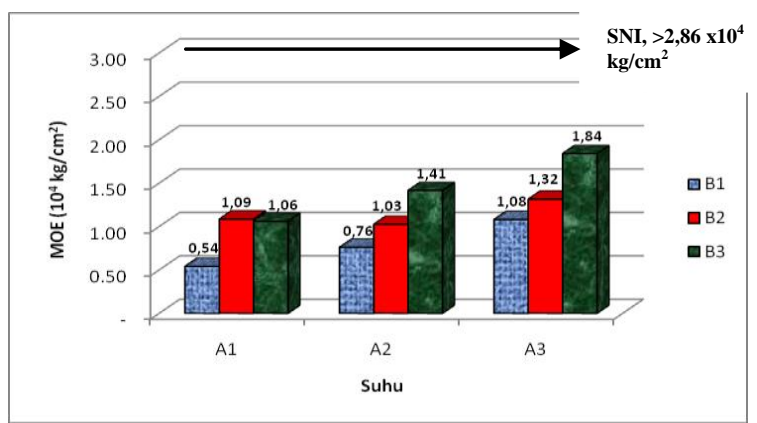

Gambar 8. MOE Papan Komposit Berlapis pada Berbagai Suhu dan Waktu Kempa

Papan komposit pada suhu pengempaan $130^{\circ} \mathrm{C}$, nilai MOE-nya meningkat pada lamanya waktu pengempaan 15 menit dengan waktu 25 menit, dan ada penurunan sedikit dengan waktu 35 menit. Hal ini menunjukkan diatas waktu pengempaan 25 menit penurunan kadar air papan komposit sangat sedikit sekali, keadaan ini juga berpengaruh terhadap kekakuan papan komposit.

Dari hasil sidik ragam diketahui bahwa variasi suhu dan waktu pengempaan tidak berpengaruh nyata terhadap modulus elastisitas papan, dan tidak ada interaksi kedua faktor tersebut. Jika dibandingkan dengan standar SNI 03-2105-2006 yang menetapkan nilai MOE papan berlapis vinir minimal 2,01 x $10^{4} \mathrm{~kg} / \mathrm{cm}^{2}$, semua papan yang telah dihasilkan pada suhu $130{ }^{0} \mathrm{C}$, $145{ }^{0} \mathrm{C}$ dan $160{ }^{0} \mathrm{C}$ pada suhu kempa 35 menit, 25 menit dan 15 menit belum memenuhi standar SNI tersebut.

Internal Bond (IB): Keteguhan rekat papan komposit yang dihasilkan berkisar antara $3,42 \mathrm{~kg} / \mathrm{cm}^{2}-4,34 \mathrm{~kg} / \mathrm{cm}^{2}$. Nilai keteguhan rekat tertinggi pada papan komposit dengan suhu pengempaan $160^{\circ}$ $\mathrm{C}$ dengan waktu 35 menit, dan terendah pada papan komposit dengan suhu pengempaan $145^{\circ} \mathrm{C}$ dengan waktu 35 menit. Nilai rata-rata pengujian disajikan pada Gambar 9.

Nilai keteguhan rekat papan komposit semakin besar dengan naiknya suhu dan waktu pengempaan. Keadaan ini dapat dilihat pada papan komposit dengan suhu pengempaan $130^{\circ} \mathrm{C}$ dan suhu pengempaan $160^{\circ} \mathrm{C}$ dengan beberapa variasi lamanya pengempaan, tetapi pada suhu pengempaan $145^{\circ} \mathrm{C}$ nilai keteguhan rekat papan komposit semakin menurun dengan lamanya waktu pengempaan, dari $4,30 \mathrm{~kg} / \mathrm{cm}^{2}$ pada waktu kempa 15 menit turun $\mathrm{ke} 4,16 \mathrm{~kg} / \mathrm{cm}^{2}$ waktu 25 menit dan $3,42 \mathrm{~kg} / \mathrm{cm}^{2}$ dengan waktu 35 menit. Hal ini kemungkinan disebabkan oleh panas pengempaan $130^{\circ} \mathrm{C}$ dan lama pengempaan 15 menit paling baik dalam pengerasan dan pematangan perekat sehingga terbentuk garis rekat yang baik yang ditandai dengan tingginya nilai keteguhan rekat yang dihasilkan. Selanjutnya waktu pengempaan 25 menit dan 35 menit dapat mengakibatkan terjadinya evaporasi molekul air dan lapisan anyaman sehingga melepuh dan menurunkan keteguhan rekatnya.

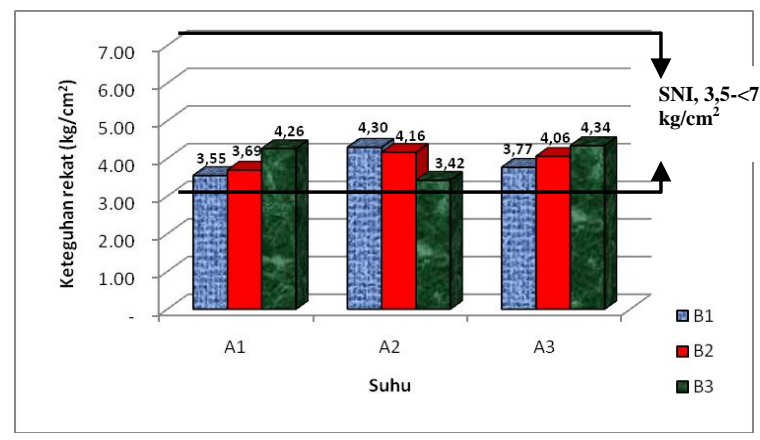

Gambar 9. Nilai Keteguhan Rekat Papan Komposit Berlapis pada Berbagai Suhu dan Waktu Kempa 
Berdasarkan analisis hasil sidik ragam, keteguhan rekat papan komposit tidak dipengaruhi oleh suhu dan waktu pengempaan, dan tidak ada interaksi pada kedua faktor tersebut. Jika dibandingkan dengan standar SNI 01-5008.7-1999 yang menetapkan nilai keteguhan rekat papan berlapis struktural minimal $3,5 \mathrm{~kg} / \mathrm{cm}^{2}$, maka papan komposit berlapis anyaman bambu yang dihasilkan memenuhi standar SNI tersebut.

Nilai Keteguhan Tekan Sejajar Serat: Nilai keteguhan tekan sejajar serat papan komposit berkisar antara 80,94 $\mathrm{kg} / \mathrm{cm}^{2}-119,77 \mathrm{~kg} / \mathrm{cm}^{2}$. Nilai keteguhan tekan yang tertinggi papan komposit pada suhu pengempaan $160^{\circ} \mathrm{C}$ dengan waktu pengempaan 35 menit, dan nilai keteguhan tekan papan yang terendah pada suhu pengempaan $130^{\circ} \mathrm{C}$ dengan waktu pengempaan 15 menit. Nilai kekuatan tekan sejajar serat disajikan pada Gambar 10.

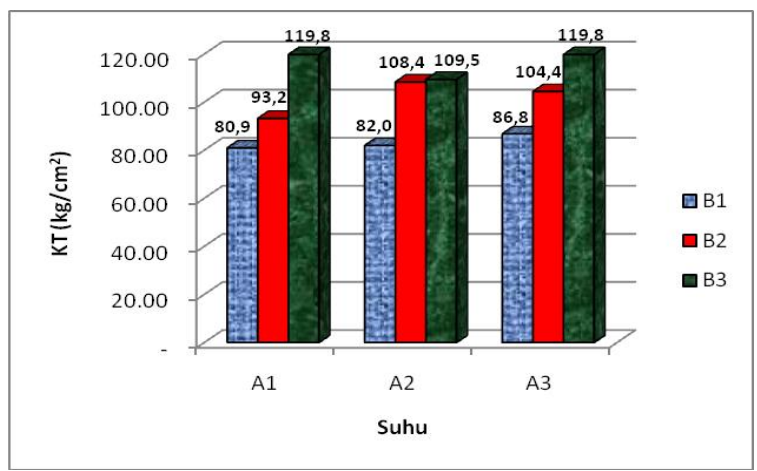

Gambar 10. Keteguhan Tekan Sejajar Serat Papan Komposit Berlapis pada Berbagai Suhu dan Waktu Kempa

Berdasarkan histogram tersebut, maka papan pada suhu pengempaan $160{ }^{\circ} \mathrm{C}$ mempunyai keteguhan tekan sejajar serat yang tinggi dibandingkan dengan papan pada suhu pengempaan $145{ }^{\circ} \mathrm{C}$ dan $130{ }^{\circ} \mathrm{C}$. Dari hasil sidik ragam, menunjukkan bahwa variasi suhu kempa tidak berpengaruh nyata terhadap nilai keteguhan tekan papan komposit, dan sebaliknya waktu pengempaan berpengaruh nyata, dan tidak adanya interaksi diantara kedua faktor tersebut.

\section{SIMPULAN}

Variasi suhu dan waktu kempa berpengaruh nyata terhadap kerapatan, kadar air, pengembangan tebal, dan MOR papan komposi, sebaliknya tidak berpengaruh nyata terhadap keteguhan rekat dan keteguhan sejajar serat.

Papan komposit berlapis yang dikempa pada suhu $130^{\circ} \mathrm{C}$ mempunyai sifat fisis dan mekanis yang lebih rendah dibanding papan yang dikempa pada suhu $145^{\circ} \mathrm{C}$, dan $160^{\circ} \mathrm{C}$. Waktu pengempaan selama 25 menit menghasilkan papan yang lebih baik dari papan yang dikempa selama 15 menit, dan kombinasi antara waktu 25 menit-suhu $145^{\circ} \mathrm{C}$ merupakan kombinasi yang optimal untuk perekat gambir untuk matang jika digunakan pada kadar air serat $8,4 \%$.

Penggunaan lapisan anyaman bambu pada papan komposit yang dihasilkan, nilai sifat fisik dan mekaniknya yang memenuhi standar SNI 03-21052006 untuk standar papan partikel berlapis finir yaitu, kerapatan, kadar air, PT24, dan MOR sedangkan nilai MOE tidak memenuhi standar. Untuk nilai kekuatan rekat papan komposit yang dihasilkan memenuhi standar SNI 01-5008.7-1999 yang menetapkan nilai keteguhan rekat papan berlapis struktural minimal 3,5 $\mathrm{kg} / \mathrm{cm}^{2}$.

\section{DAFTAR PUSTAKA}

[Deptan] Departemen Pertanian. 2015. Statistik Perkebunan Indonesia (2009-2015)

Junaidi, Anwar Kasim, Adrinal., 2016. Pengembangan Mesin Pengurai Serat Tandan Kosong Kelapa Sawit (TKKS) Untuk Menghasilkan Serat Mekanis. Jurnal Litbang Industri Baristand Industri Padang Vol. 6 No. 1, Juni 2016. (terakreditasi No. 558/AU1/P2MI-LIPI/09/2013) 
Kasim. 2002. Proses Gambir Sebagai Bahan Baku Perekat. Paten Nomor Pendaftaran P. 00200200856.

Sumadiwangsa. 1982. Pengaruh Bahan Penguat Pada Bahan Perekat Tanin Bakau-Bakau (Rhizophoraceae) terhadap Sifat-Sifat Papan Partikel. [tesis]. Program Pascasarjana IPB. Bogor.

Syafii W. 2000. Pemanfaatan Tanim Kulit Kayu Acacia Decurrens Wild Sebagai Bahan Baku Perekat untuk Pembuatan Papan Serat. Jurnal II Pertanian Indonesia. Vol. 9 (1). Hal. $12-18$.

Cicilia. 2000. Autokondensat Tanin dan Penggunaannya sebagai Perekat Kayu Lamina. [Tesis]. Program Pascasarjana IPB.

I Putu J.A. 2005. Ekstrak Kulit Pohon Mangium sebagai Bahan Perekat Tanin Resorsisol Formaldehida untuk Pembuatan Papan Partikel. [Tesis]. Program Pascasarjana IPB.

Umi Fathanah, Sofyana. 2013. Pembuatan Papan Partikel (Particle Board) dari Tandan Kosong Sawit dengan Perekat Kulit Akasia dan Gambir. Jurnal Rekayasa Kimia dan Lingkungan Vol. 9, No 3, hal 137143 ISSN 1412-5064.

Kasim. A. 2011. Proses Produksi dan Industri Hilir Gambir. Andalas University Press. Padang.

Haygreen J.G, Bowyer J.L. 1992. Forest Products and Science, an Introduction. Ames Iowa USA : Iowa State University Press

Sudijono, Subyakto. 2002. Bending and Shear Properties of low Density Particleboard Laminated with Zephyr of Tali Bamboo. Di dalam :
Dwianto W, Yusuf S, Hermiati E, Suryanegara L, editor. Proceedings of the International Wood Science Symposium. JSPS-LIPI Core University Program ; Serpong, 2 - 5 September 2002.

Setyawati D. 2009. Pemanfaatan Serat Sabut Kelapa dan Plastik Daur Ulang untuk Papan Komposit Berlapis Anyaman Bambu [disertasi]. Program Pascasarjana, Institut Pertanian Bogor. Bogor.

Erniwati. 2008. Pengembangan Papan Komposit Berlapis Anyaman Bambu dari Jenis Kayu Cepat Tumbuh dengan Perekat Poliuretan [disertasi]. Program Pascasarjana, Institut Pertanian Bogor. Bogor.

Maloney. T.M. 1993. Modren Particleboard and Dry-Proces Fiberboard Manufacturing. Edisi Revisi. USA : Miller Freeman Inc San Francisco.

Kollman. F. F. P, E. W. Kuenzi and A. J. Stamm. 1975. Principle of Wood Science and Technology. Wood Based Materials. Vol II. SpringerVerlag Berlin Heidelberg-New York.

Kasim A. 2007. Pengaruh Suhu dan Lama Pengempaan pada Pembuatan Papan Partikel dari Batang Kelapa Sawit (Elaeis guineensis Jacq.) dengan Perekat Gambir (Uncaria gambir Roxb.) terhadap Sifat Papan Partikel. Jurnal Tropical Wood Science and Technology Vol.5 No. 1. Hal $18-21$

Erniwati, Hadi YS, Masijaya MY. 2008. Pengaruh Suhu dan Waktu Kempa terhadap Kualitas Papan Komposit Berlapis Anyaman Bambu. Jurnal RIMBA Kalimantan Fakultas Kehutanan Universitas Mulawarman, Vol. 13 No. 2. 
Sutigno P. 1988. Perekat dan Perekatan.

Puslitbanghut. Departemen

Kehutanan. Bogor

SNI 03-2105-2006. Papan Partikel Datar.

Dewan Standarisasi Nasional

Indonesia.

SNI 01-5008.7-1999. Kayu Lapis Struktural. Dewan Standarisasi Nasional Indonesia.

Kelly, M.W., 1977, Critical Literature Review of Relationship between Processing Parameters and Physical Properties of Particle-board. USDA for. Serv. Gen. Tech. Rep. FPL-10.

Ruhendi, S, dkk,. 2007. Analisis Perekatan kayu. Fakultas Kehutanan Institut Pertanian Bogor. Gajah Mada Universitas Press Yogyakarta. 